\title{
Access to Information Law in Brazil: What the Implementation Data Reveal
}

The Access to Information Law (AIL) in Brazil was introduced on November 18, 2011 (Law n. 12,527), implementing some provisions of the Federal Constitution: item XXXIII of the article $5^{\circ}$; item II, paragraph $3^{\circ}$, of the article 37 ; and paragraph $2^{\circ}$ of the article 216 . This law, with 47 articles, provides rules to be implemented concerning administrative procedures to the citizens accessing information, deadlines, restrictions, information publishing, accountability of the public servants, and other complementary items. The Brazilian AIL is amongst the most complete laws of this kind in the world, a cultural trace of a long time Weberian legislative tradition in the country.

Access to Information Law (AIL) has become, in the last decades, the most common countermeasure recommended by multilateral organisations to fight corruption in the government around the world (Organisation for Economic Co-operation and Development, 2001; United Nations Educational, Scientific and Cultural Organisation, 2019, 2020). In fact, although the idea of granting citizens the access to governmental information has not been written in a law for the first time in USA, in the post-Internet age was an American ex-President who published an enlightening manifesto in benefit of this kind of initiative. In the preface of a report on access to information, he stated that:

(...) The information access is a crucial element of the efforts aimed to reducing corruption, enhancing governmental accountability with the population, and strengthening the confidence between government and citizens. The public access to information withheld by government allows citizens to better understanding about the role of the government and decisions that it makes on their behalf. (Neumann, 2002, 3, our translation)

The Carter's manifesto is not important just for explaining the political (democratic) principle behind an AIL, but also for a sense of reality revealed in the message, perhaps resulted 
from his experience with the implementation of democracy "in the trenches", as we can see in another excerpt:

In those branches where the access to information have been implemented, the requests commonly do not search for high level policies information and governmental management. On the opposite, more often users of the access laws trend to be individuals or companies who search for information concerned administrative activities that directly impact them. (Neumann, 2002, 9, our translation)

In 2015 the progress of the access to information all over the world become also a goal in the "2030 Agenda for Sustainable Development" under the monitoring of the United Nations Educational, Scientific and Cultural Organisation (UNESCO). The access to information, according to UNESCO (2020), is a human right and when citizens have access to information held by public bodies, societies as a whole are empowered to contribute to sustainable development.

Other important reports pro access to information laws in the countries have been published in the last two decades, some of them also with a foot in the "trenches" of public policy. For example, a report of the Organisation for Economic Co-operation and Development (OECD) states that:

When embarking on strengthening government-citizen relations, building a framework is a prerequisite. A framework provides the setting in which these relations can evolve and be strengthened. It is about the legal rights of citizens to information, consultation and active participation, about government policies and about the institutions charged with the tasks. (OECD, 2001, 27)

In short, the OECD's report explains the several benefits for democracy (and free market, although not much discussed in the report) of an access to information initiative and shows a set of recommendations on best practices to implement it in the countries. The Access 
to Information Law's (LAI, in Portuguese) Web Portal of the Office of the Comptroller General (CGU), which is the ministry of the federal control in Brazil, was built, in a great extent, as recommended by the OECD. Starting with the name "e-SIC" (meaning "Information Service to Citizens") in 2012, when it was implemented, nowadays the computing information system that supports the citizens in the process to access information through the Internet in the Federal Government is integrated in a major ICT public platform called "Fala-BR" (translated as "TalkBrazil"): https://www.gov.br/acessoainformacao/pt-br.

Evaluations of the access to information laws in the countries with empirical data on the point of view of user satisfaction are still scarce, a lack of published knowledge that motivated the research presented in this article. Commonly, the literature shows interesting articles and reports on the political conception of the law in the countries (Neumann, 2002; OECD, 2001; Rodrigues, 2020; UNESCO, 2020; Worthy, 2015) and some perceptions of its implementation, but with qualitative methodology and data collected only by surveys applied to experts and public servants (Mabilard, 2016; Mabilard, Sofia and Pasquier, 2019; Open Society Institute, 2006; UNESCO, 2019; Worthy, 2015).

There are also some non-profit organisations working in the watchdogging of the implementation pace of the laws in the countries, like the Centre for Law and Democracy (https://www.law-democracy.org/live/rti-rating/global/), which publish the "Global RTI Rating". This is an interesting rating scale on the maturity level of the countries regarding some evolutive performance indicators where, in a universe of 128 assessed countries, Brazil is in the $29^{\text {th }}$ position, with an outcome of 108 points obtained in an evaluation scale of a maximum of 150 points. Other report that places Brazil in a good position regarding the implementation of the law is the last publication of UNESCO (2019) on the thema.

In the research presented in this article, the collected empirical data resulted of the running process to accessing information in the Brazilian Federal Government since 2013 
published in another Web Portal called "Access to Information Law Portal” (in Portuguese: "Portal da Lei de Acesso à Informação"; http://paineis.cgu.gov.br/lai/index.htm). This Web Portal is a work of the Office of the Comptroller General (CGU), made available to everyone minimally skilled to browsing in the Internet a lot of data automatically collected during the (past) operational transactions of accessing governmental information by the citizens since 2012 to 2021. These data are updated daily and, for the use of the search engine in a "drill down" On Line Analytical Processing (OLAP), can be segmented by agency, year, month, day, and any period combining these time fields at the beginning and at the end of a historical time period of data recovery.

However, amongst the data available to the public three indicators are of the most interest to the research presented in this article: Number of Requests for Information (NRI), Mean Response Time (MRT), and Level of User Satisfaction (LUS). The meaning of each one of these three indicators is as follows:

a) NRI: the number of times citizens requested access to information withheld by any government agency or state-owned company in any period of time;

b) MRT: the mean time that the requested government bodies took to answer the citizens' requests for information, calculated in any period of time (remembering that the deadline to response by the Law n. 12,527/2011 is 20 days, which can be, with good reason, postponed for another 10 days by the requested agency or stateowned company);

c) LUS: the mean level of user (citizen's) satisfaction with the response received from the requested agency or state-owned company; the satisfaction level of each response is assessed by the user (citizen) just after receiving the answer sent by the government body, measured (qualitatively) in a Likert scale (Joshil et. al., 2015) 
with values between 1 (the poorest level of user satisfaction) and 5 (the highest level of user satisfaction).

With data analysis of the Level of User Satisfaction (LUS) indicator we tried to answer, as the main objective of the research, the following question: "How satisfied are the AIL's users in Brazil?" Other important questions discussed in this article, based on outcomes of data analysis and the Expectancy-Disconfirmation Theory (EDT) are: "How evolved the agencies on the user level of satisfaction since 2013, the first entire year implementing the AIL? Is there some meaningful statistical correlation between the three indicators before mentioned? What are the best and the worst agencies dealing with the AIL in the past and present? Are there some interesting data patterns in the historical series for the purpose of knowledge creation to improve the process of access to information?"

\section{Research Methodology}

Combining data analysis with the Expectancy Theory, in its evolutive version called "Expectancy-Disconfirmation Theory (EDT)", the evaluation of the implementation process of the Access to Information Law (AIL) in Brazil is based on a cognitive framework adequate to the case, explained as follows. In the first step of the research, we employed statistical techniques for data analysis, culminating with the structuring of a datasheet showing the main statistical parameters to the assessment of historical data series. The further step was dedicated to eliminate any possible misunderstanding of the "expectancy-disconfirmation" concept, that is a subjective evaluation in some extent.

\section{Expectancy-Disconfirmation Theory}

The "Expectancy-Disconfirmation Theory" (Chatterjee and Suy, 2019; Grimmelikhuijsen and Porumbescu, 2017; Oliver, 1980; Purvis, Zagenczyk and McCray, 2015; Yüksel and Yüksel, 2007) states that a level of customer's satisfaction with some product (good or service) provided to him by a supplier depends always of what the customer expected before 
receiving the product. This "what" may be a set of valued attributes of the requested good or service concerning its performance, quality, price, delivery deadline, durability, maintaining cost, etc. The level of customer's satisfaction is evaluated by the difference (quantitative or qualitative) between the expectation (before receiving) and the evaluation about the received good or service (after receiving it).

Since the 1950s several researchers have presented issues on the concept of "satisfaction" and Oliver (1977, 1980) proposed the Expectancy-Disconfirmation Paradigm (EDP) as the most promising theoretical framework for the assessment of customer satisfaction, stating that if the outcome (product or service) matches the expectation, then occurs a confirmation, and if the outcome do not match the expectation, then occurs a disconfirmation. Another way of reasoning is that if a customer may have a "positive disconfirmation" on a requested product delivered by the supplier, it is considered better than what he expected; and may have a "negative disconfirmation" in the opposite, if the delivered product is considered worse than what the customer expected.

Van de Walle (2018), in a research on the citizen satisfaction and dissatisfaction with public services around the world, concluded with the need to take into account social and political variables in the evaluations of citizen' satisfaction with public services, also stating that in recent years the EDT has been adopted by European public management scholars. Yet, despite the complexity of such kind of evaluation and the criticisms addressed to EDT-based methodologies, as pointed out by Yüksel and Yüksel (2007), this is an evidence that the best we can do in situations where the product performance cannot be judged discretely (remembering that the product, in this case, is "information") is to use EDT carefully, with some adjustments and adaptations to the context.

In Figure 1 is presented a general process of evaluating a consumer's satisfaction in a product delivering experience with 12 possible pathways. Then, starting with the cognitive step 
"Building an Expectation" (columns bloc "A"), the customer may have or not a prior knowledge of a similar product, what sends him to four alternate pathways next in the process: expecting a better than a similar product, expecting a similar product, expecting a worse than a similar product, or expecting a satisfactory product with no prior reference (in this process pathway, the evaluation will carry on with no baseline, then being more subjective).

Figure 1

Pathways of Expectancy Confirmation/Disconfirmation Process

\begin{tabular}{|c|c|c|c|c|c|}
\hline \multicolumn{3}{|c|}{ A } & \multicolumn{2}{|c|}{ B } & $\mathrm{C}=\mathrm{B} / \mathrm{A}$ \\
\hline \multicolumn{3}{|c|}{ Building an Expectation } & \multicolumn{2}{|c|}{$\begin{array}{c}\text { Building Confirmation / } \\
\text { Disconfirmation along the } \\
\text { Experience }\end{array}$} & $\begin{array}{l}\text { Evaluation of } \\
\text { Satisfaction }\end{array}$ \\
\hline \multirow{3}{*}{$\begin{array}{l}\text { a) Knowing } \\
\text { Similar } \\
\text { Products }\end{array}$} & I & $\begin{array}{l}\text { Expecting a better } \\
\text { than a similar } \\
\text { product. }\end{array}$ & 1 & $\begin{array}{l}\text { Non-Previewed } \\
\text { Positive Experiences }\end{array}$ & \multirow{6}{*}{$\begin{array}{l}\text { Confirmation / } \\
\text { Disconfirmation }\end{array}$} \\
\hline & II & $\begin{array}{l}\text { Expecting a } \\
\text { similar product. }\end{array}$ & 2 & $\begin{array}{l}\text { Previewed } \\
\text { Experiences }\end{array}$ & \\
\hline & III & $\begin{array}{l}\text { Expecting a worse } \\
\text { than a similar } \\
\text { product. }\end{array}$ & 3 & $\begin{array}{l}\text { Non-Previewed } \\
\text { Negative } \\
\text { Experiences }\end{array}$ & \\
\hline \multirow{3}{*}{$\begin{array}{l}\text { a) Not- } \\
\text { Knowing } \\
\text { Similar } \\
\text { Products }\end{array}$} & \multirow{3}{*}{\multicolumn{2}{|c|}{$\begin{array}{l}\text { IV. Expecting a } \\
\text { "satisfactory" product. }\end{array}$}} & 4 & Positive Experiences & \\
\hline & & & 5 & Neutral Experiences & \\
\hline & & & 6 & $\begin{array}{l}\text { Negative } \\
\text { Experiences }\end{array}$ & \\
\hline
\end{tabular}

In the next cognitive step (columns bloc "B" in Figure 1) of this evaluation process, the activity is to build a "confirmation/disconfirmation" output, which is supposed to occur cumulatively along the customer's experience with the good or service received. Obviously, an experience of evaluating a product received by a customer may require days or months, but is supposed, for the purpose of this research, that the citizen's evaluation of some information 
provided by a government body requires no such delays and the reaction survey applied just after the citizen has received the response is close to a complete and fair evaluation.

Identifying each pathway in the process by its logical "route", the pathway "AaI1", for example, occurs when the customer has prior knowledge of a similar service (Aa), expected a better than a similar service (I), and received a service perceived as a non-previewed positive experience (1). So, the twelve pathway possibilities, ending with "confirmation" or "disconfirmation", are:

- confirmation: AaI1, AaI2, AaII1, AaII2, AaIII1, AaIII2, AbIV4, AbIV5;

- disconfirmation: AaI3, AaII3, AaIII3, AbIV6.

Considering the product "information" in each context of a citizen accessing to government bodies information, on one hand it may be difficult to compare the specific information expected by a citizen with a similar one acknowledged by him before. On the other hand, this difficulty left us in the pathways with more subjective evaluations AbIV4, AbIV5, AbIV6, which are (fortunately) adequate to be processed with the citizen satisfaction data provided by the CGU's information system used in the research.

\section{Information Relevance}

The type of information requested by the citizens is "useful information", which can be considered the information relevant to the citizens (system users) in their personal context. As an important concept to Information Science (Choo, 2005), "relevant information" is also useful to several areas of knowledge such as Economics (Stiglitz, 2009; Birchler and Bütler, 2007), Electronic Engineering (Shannon, 1948) and Psychology (Bateson, 2002; Weick, 1995).

Bateson (2002) presents the best concept of "relevant information" for the purposes of the research published in this article, summed up in the statement that information is "the difference which makes difference". This statement is referred to the cognitive experience of contrast between a new and a prior perception of some object of knowledge and Bateson (2002) 
argue that information relevance can be something simple in the day-to-day, as when a person find an information of interest in a newspaper: to be valuable to the reader, the information must be a novelty, i.e., the information must be different, contrasting with the set of information the reader had before.

In the real world of access to information processes and systems, it makes sense to suppose, as a research premise, that citizens request relevant information to their own interest in a context (Neumann, 2002; Worthy, 2015), which leads us to the conclusion that makes more sense the reasoning where the citizens ask for information not acknowledged before. Obviously, citizens also request governmental information to validate presumptions (in a confirmation pathway) with the aid of a trustful source, like often journalists do before the publication of a story, but even in this case the citizen (a journalist) has not for granted the expected information from the government body, a situation that not invalidate our premise.

This premise of citizens "self-interest" in accessing information through the communication channel of the AIL is reinforced by recent advances in the Open Data agenda in Brazil (Bittencourt, C.; Estima, J. and Pestana, G., 2019; Fundação Getúlio Vargas, 2019), another source of government information where that too much wanted empirical data on the implementation of public policies, programs and projects are freely published in the Internet.

The CGU's AIL system also stores data on the user profile, which allow a classification of the information requesters by professional occupation. Meanwhile, considering the occupation data are not obligatory to use the system, a very significative share of the citizens do not declare its profession, resulting that $39,9 \%$ of the users (citizens) are of unknowledge profession and just $1,1 \%$ identify itself as a journalist.

A last methodological issue must be addressed before we start the presentation of data analysis: as the user (citizens) satisfaction level with a response is measured in a Likert scale (Joshil et al., 2015) ranging between 0 (zero) and 5 (five), it raises the question: what is to be 
considered "satisfactory" (confirmation) and "unsatisfactory" (disconfirmation) in this measuring scale? Although recognising the task of structuring a cognitive framework to mapping responses in a Likert scale could be not simple, we took a leveling approach as simple as possible with the citizen satisfaction indicator: from 0.00 (zero) to 2.50 (two point fifty) the response would be "unsatisfactory" and from 2.51 (two point fifty one) to 5.00 (five) would be "satisfactory".

A possible interpretation of this Likert scale, concerning the Level of User Satisfaction (LUS) indicator, could be: 0.00 to 1.00 , too much unsatisfactory; 1.01 to 2.00 , unsatisfactory; 2.01 to 3.00 , more or less satisfactory; 3.01 to 4.00 , satisfactory; 4.01 to 5.00 , too much satisfactory. Notwithstanding other qualitative scales could be used, this interpretive scale of LUS is then used as a first approach to analysing data in the research.

\section{Data Analysis and Discussion}

Despite the CGU's information system has been available since 2012, for the purpose of the research presented in this article the collected dataset on the operational process of implementing the AIL shows 299 agencies and state-owned companies of the Federal Government in Brazil with data from 2013 to 2020. In these eight years of operation, the system stored 919,366 cumulative requests for information (RFI) by the citizens, being the most requested agency the Ministry of Economy, with 104,318 RFIs, and the less requested one (a state-owned company) the Dock Company of Rio Grande do Norte, with only 32 RFIs. Calculating the two main indicators with the selected dataset in a cumulative approach since 2013 to 2020, we have 21.00 days for the Mean Response Time (MRT) and 4.08 for the Level of User Satisfaction (LUS) in a scale range from 0.0 (zero) to 5.0 (five).

\section{Performance Indicators by Government Bodies}

A sample of this selected dataset is presented in Table 1, showing the name and legal type of the 26 most requested federal government's agencies and state-owned companies and 
their performance indicators NRI (Number of Requests for Information), MRT (Mean Response Time, in days) and LUS (Level of User Satisfaction, in the Likert scale between 0.0 to 5.0) in 2020. Cumulatively, all of these 26 government bodies reported in the system more than ten thousand RFIs in the period, a number used as a technical parameter to cut off the agencies and state-owned companies' data sample to be analysed, summing up 602,698 RFIs (or $65.6 \%$ of the statistical universe).

Table 1

Performance Indicators by Agency and State-Owned Company

\begin{tabular}{|c|c|c|c|c|c|}
\hline \multicolumn{3}{|c|}{ Federal Government Body } & \multicolumn{3}{|c|}{$\begin{array}{l}\text { Performance Indicator } \\
\qquad(2012-2020)\end{array}$} \\
\hline$\#$ & Name (1) & Legal Type & NRI & MRT & LUS \\
\hline 1 & Ministry of Economy (ME) & Ministry & 104,318 & 12.3 & 3.70 \\
\hline 2 & National Institute of Social Insurance (INSS) & Autarchy & 54,548 & 5.2 & 3.46 \\
\hline 3 & Ministry of Citizenship (MCIDADANIA) & Ministry & 37,268 & 12.8 & 3.24 \\
\hline 4 & Federal Savings Bank (CEF) & $\begin{array}{c}\text { State-Owned } \\
\text { Company }\end{array}$ & 33,681 & 10.5 & 2.96 \\
\hline 5 & National Agency of Electric Energy (ANEEL) & $\begin{array}{l}\text { Regulatory } \\
\text { Agency }\end{array}$ & 32,657 & 6.8 & 4.24 \\
\hline 6 & Ministry of Health (MS) & Ministry & 31,656 & 20.5 & 3.70 \\
\hline 7 & $\begin{array}{l}\text { Superintendence of Private Insurance } \\
\text { (SUSEP) }\end{array}$ & Autarchy & 26,585 & 1.8 & 3.73 \\
\hline 8 & Ministry of Education (MEC) & Ministry & 24,285 & 19.2 & 3.75 \\
\hline 9 & Central Bank (BACEN) & Autarchy & 22,843 & 3.4 & 3.72 \\
\hline 10 & $\begin{array}{l}\text { National Institute of Educational Studies and } \\
\text { Researches Anísio Teixeira (INEP) }\end{array}$ & Autarchy & 21,110 & 9.4 & 3.71 \\
\hline 11 & $\begin{array}{l}\text { Ministry of Agriculture, Livestock and Supply } \\
\text { (MAPA) }\end{array}$ & Ministry & 21,035 & 20.1 & 3.90 \\
\hline 12 & $\begin{array}{l}\text { National Agency of Health Surveillance } \\
\text { (ANVISA) }\end{array}$ & $\begin{array}{l}\text { Regulatory } \\
\text { Agency }\end{array}$ & 17,636 & 14.5 & 3.97 \\
\hline
\end{tabular}




\begin{tabular}{|c|c|c|c|c|c|}
\hline 13 & Brazilian Post and Telegraph Company (ECT) & $\begin{array}{c}\text { State-Owned } \\
\text { Company }\end{array}$ & 17,508 & 15.8 & 2.73 \\
\hline 14 & Brazilian Oil (PETROBRAS) & $\begin{array}{c}\text { State-Owned } \\
\text { Company }\end{array}$ & 16,576 & 15.1 & 4.14 \\
\hline 15 & $\begin{array}{l}\text { Brazilian Institute of Environment and } \\
\text { Renewable Natural Resources (IBAMA) }\end{array}$ & Autarchy & 13,986 & 17.6 & 3.63 \\
\hline 16 & Department of Federal Police (DPF) & $\begin{array}{l}\text { Ministerial } \\
\text { Department }\end{array}$ & 13,764 & 12.2 & 3.72 \\
\hline 17 & $\begin{array}{l}\text { National Agency of Waterway Transport } \\
\text { (ANTAQ) }\end{array}$ & $\begin{array}{l}\text { Regulatory } \\
\text { Agency }\end{array}$ & 13,070 & 6.0 & 4.35 \\
\hline 18 & $\begin{array}{l}\text { National Department of } \quad \text { Transport } \\
\text { Infrastructure (DNIT) }\end{array}$ & Autarchy & 12,654 & 9.7 & 3.52 \\
\hline 19 & $\begin{array}{l}\text { Ministry of Justice and Public Security } \\
\text { (MJSP) }\end{array}$ & Ministry & 11,869 & 15.5 & 3.50 \\
\hline 20 & Office of the Comptroller General (CGU) (2) & Ministry & 11,665 & 15.2 & 4.10 \\
\hline 21 & Bank of Brazil (BB) & $\begin{array}{c}\text { State-Owned } \\
\text { Company }\end{array}$ & 11,319 & 17.1 & 2.07 \\
\hline 22 & Ministry of Regional Development (MDR) & Ministry & 11,100 & 11.4 & 4.11 \\
\hline 23 & $\begin{array}{l}\text { National Agency of Telecommunications } \\
\text { (ANATEL) }\end{array}$ & $\begin{array}{l}\text { Regulatory } \\
\text { Agency }\end{array}$ & 10,775 & 11.1 & 3.65 \\
\hline 24 & Ministry of Infrastructure (MINFRA) & Ministry & 10,375 & 17.0 & 3.79 \\
\hline 25 & $\begin{array}{l}\text { Ministry of Science, Technology and } \\
\text { Innovations (MCTI) }\end{array}$ & Ministry & 10,248 & 17.7 & 3.81 \\
\hline \multirow[t]{2}{*}{26} & $\begin{array}{l}\text { National Fund of Education Development } \\
\text { (FNDE) }\end{array}$ & Autarchy & 10,167 & 11.8 & 3.53 \\
\hline & Total RFI & & 602,698 & & \\
\hline
\end{tabular}

Notes: (1) Acronyms of government bodies are in Portuguese. (2) The CGU is also evaluated by the citizens.

These data sample includes the biggest agencies and state-owned companies in the Federal Government, which have demands for the most traditional public services into the population, such as Ministry of Economy (now incorporating the former Ministry of Finance, Ministry of Planning, Development and Management, Ministry of Social Insurance, Ministry 
of Labor, and Ministry of Industry and Commerce), Ministry of Health, Ministry of Education, Ministry of Agriculture, Livestock and Supply, National Institute of Social Insurance, National Agency of Telecommunications, Brazilian Post and Telegraph Company, Brazilian Oil Company, Federal Savings Bank, and Bank of Brazil.

In beforehand, to one evaluate how representative is the data sample of Table 1, it is important to understand the traditional political economy in Brazil, where the participation of Federal Government bodies in the market is not just regulatory, but in many cases producing goods and services for the population. The Brazilian economy looks more like the European "social market economy" than the United States "free market economy", with some stateowned companies also playing market roles in industry branches such as banking, electric energy, oil and gas, railroad transport, metropolitan transport, sea ports, health care services, and education in all levels (K12, college, and university).

In the following, data in Table 2 and graphs of Figure 2, Figure 3 and Figure 4 show the evolution of the performance indicators NRI, MRT and LUS of the 26 selected Federal Government bodies in a time series since 2013 to 2020 (the data in the Figures are shown in international standard notation).

Table 2 shows the mean NRI per government body increased just $22.4 \%$ since 2013 to 2020, starting with 1,606 and ended with 1,965. If we discard the year 2020 due to the Covid19 pandemics decreasing effects on NRI and consider 2019 as the final year of the time series, the observed increase of NRI is $44.8 \%$. On the other hand, despite the MRT has decreased $21.4 \%$, the LUS increased just $8.6 \%$ in the time series period, showing some stability in the LUS during the implementation period of the AIL in Brazil.

Table 2

Time Series of AIL's Performance Indicators

Indicator Year




\begin{tabular}{|c|c|c|c|c|c|c|c|c|}
\hline & 2013 & 2014 & 2015 & 2016 & 2017 & 2018 & 2019 & 2020 \\
\hline $\begin{array}{l}\text { Number of Requests for } \\
\text { Information (NRI) }\end{array}$ & 1,606 & 1,706 & 1,675 & 1,761 & 1,808 & 2,099 & 2,325 & 1,965 \\
\hline $\begin{array}{l}\text { Mean Response Time } \\
\text { (MRT) }\end{array}$ & 14.5 & 14.7 & 14.9 & 14.3 & 11.9 & 11.6 & 11.7 & 11.4 \\
\hline $\begin{array}{l}\text { Level of } \quad \text { User } \\
\text { Satisfaction (LUS) }\end{array}$ & 3.5 & 3.6 & 3.7 & 3.7 & 3.8 & 3.8 & 3.8 & 3.8 \\
\hline
\end{tabular}

In the tridimensional graph (with two vertical axis) of Figure 2, we found the first surprising perception with data analysis: when the Number of Request for Information (NRI) increased after the year 2016, the Mean Response Time (MRT) decreased, showing a (negative) Pearson correlation coefficient of -0.7984 between the two graph curves. According to the evaluation ranging scales of this statistical parameter commonly adopted, between 0.7 and 0.9 there is a strong correlation, and so we can conclude that NRI and MRT have a strong negative correlation, which means that when the first increase, the first decrease, perhaps in an actionreaction mechanism of the requested government bodies.

We also observe, in Figure 2, two levels of almost constant values for MRT, the first since 2013 to 2017 and the second from 2017 to 2020, this second showing a decreased level. The common sense tells us that if a government agency or state-owned company suddenly receives an extra workload, in the short term ahead the response time of an information service provided by the government body tends to be increased until the time when its productivity could be improved.

Figure 2

Number of Requests for Information (NRI) vs. Mean Response Time (MRT) 


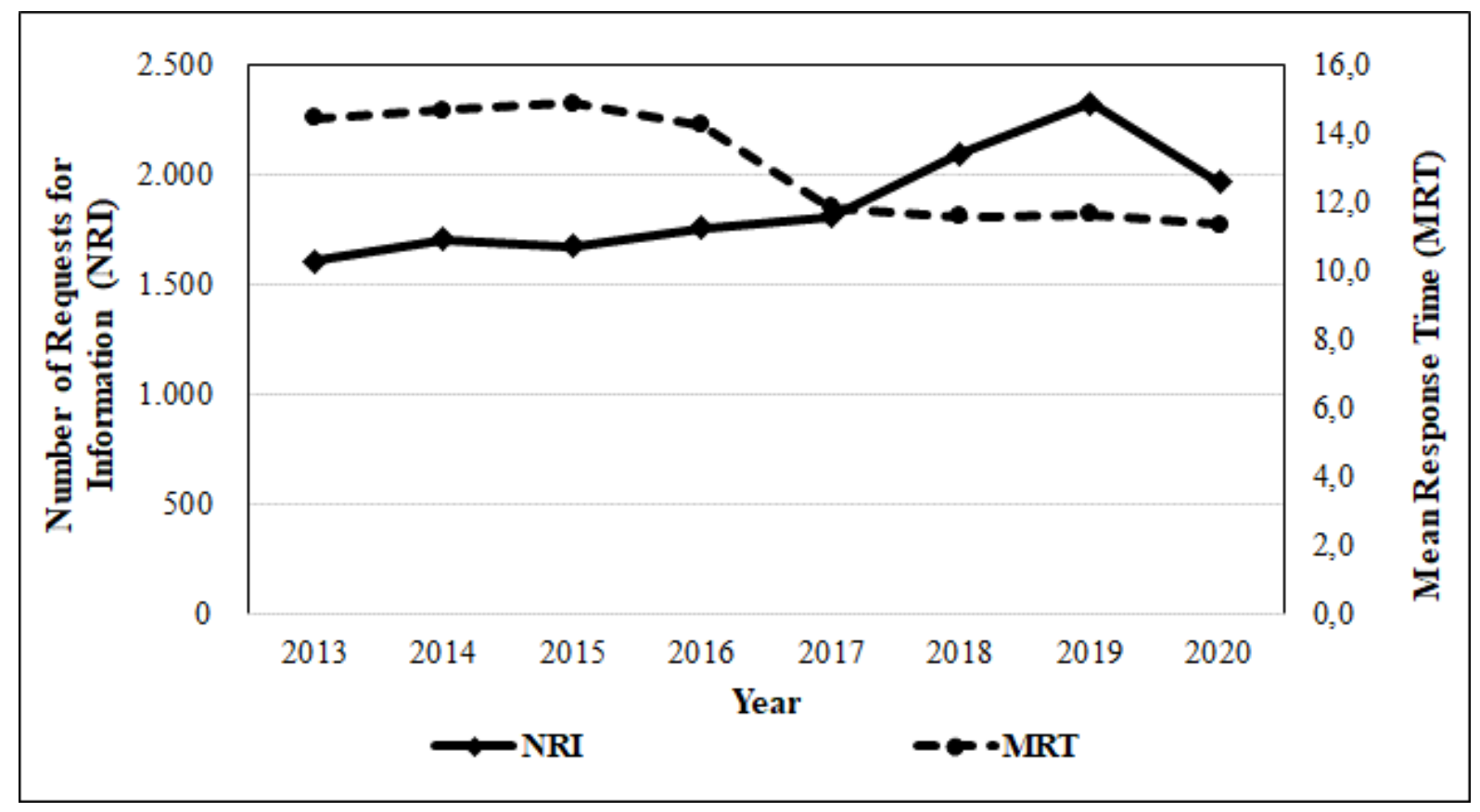

On a realistic scenario, a plausible (logically) explanation for this unexpected phenomenon is that when a government body receives an extra pression with more RFI than the average, it reacts and provides more quickly responses to the citizens in a corporate effort to avoid too much non-responded (in the deadline) RFI stored. Obviously, quicker responses could also mean responses with less quality than before, but there is no data about the response quality unless those indicated by the Level of User Satisfaction (LUS). Another hypothesis is that the requested government body, when pressed with more RFIs than the average, allocates more human resources to answer the citizens, thus alleviating the pressure and achieving some gain in scale with this effort.

The graph of Figure 3 shows how the indicators NRI and LUS have evolved over the time series, where one can see a positive Pearson correlation between both, statistically estimated to be 0.7344 (a strong correlation). It is clear that while NRI has increased, LUS has been improved by the agencies and state-owned companies in the period, showing also that an increase of the number of requests for information do not lead, necessarily, to a decrease of user satisfaction.

Figure 3 


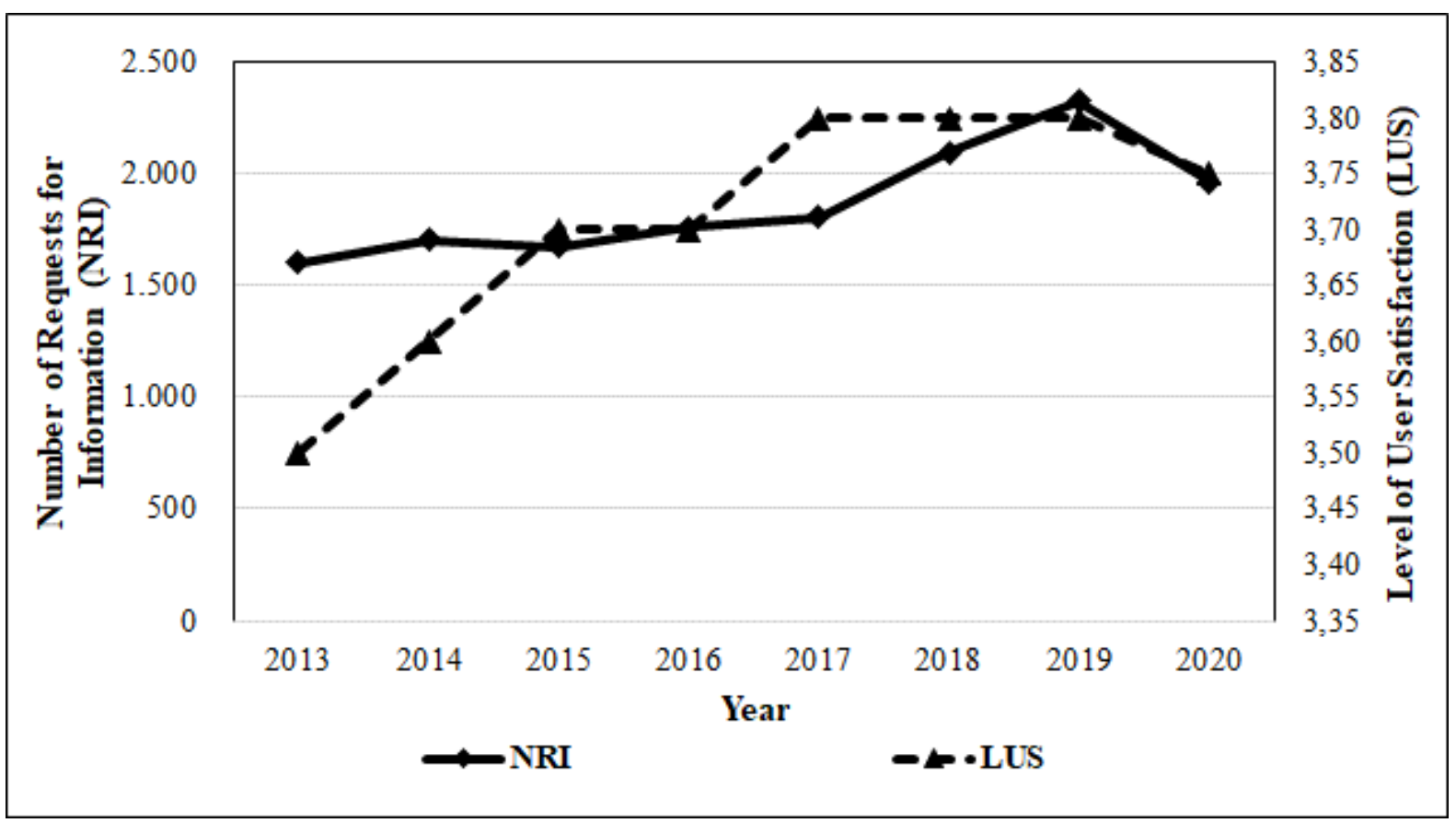

A plausible hypothesis to explain this concerted evolution of RFI and LUS is that the agencies invested to improve their performance in dealing with the AIL in the Federal Government in Brazil since the beginning, while the citizens augmented their interest in using their rights to accessing information.

In the graph of Figure 4 is shown a comparison between the time series of the indicators MRT and LUS, the third two-by-two combinatory possibility with the three indicators NRI, MRT, and LUS to data analysis. One can observe: first, a slowly decrease in the MRT from 2015 to 2017, which seems to stabilise after this period; second, the LUS increasing from 2013 to 2017 and stabilising after that year (the LUS in 2020 may be a consequence of the government agencies' service quality declining due to Covid-19's pandemics). The Pearson coefficient between MRT and LUS shows that there is also a significant and negative statistical correlation (- 0.7722).

Figure 4

Mean Response Time (MRT) vs. Level of User Satisfaction (LUS) 


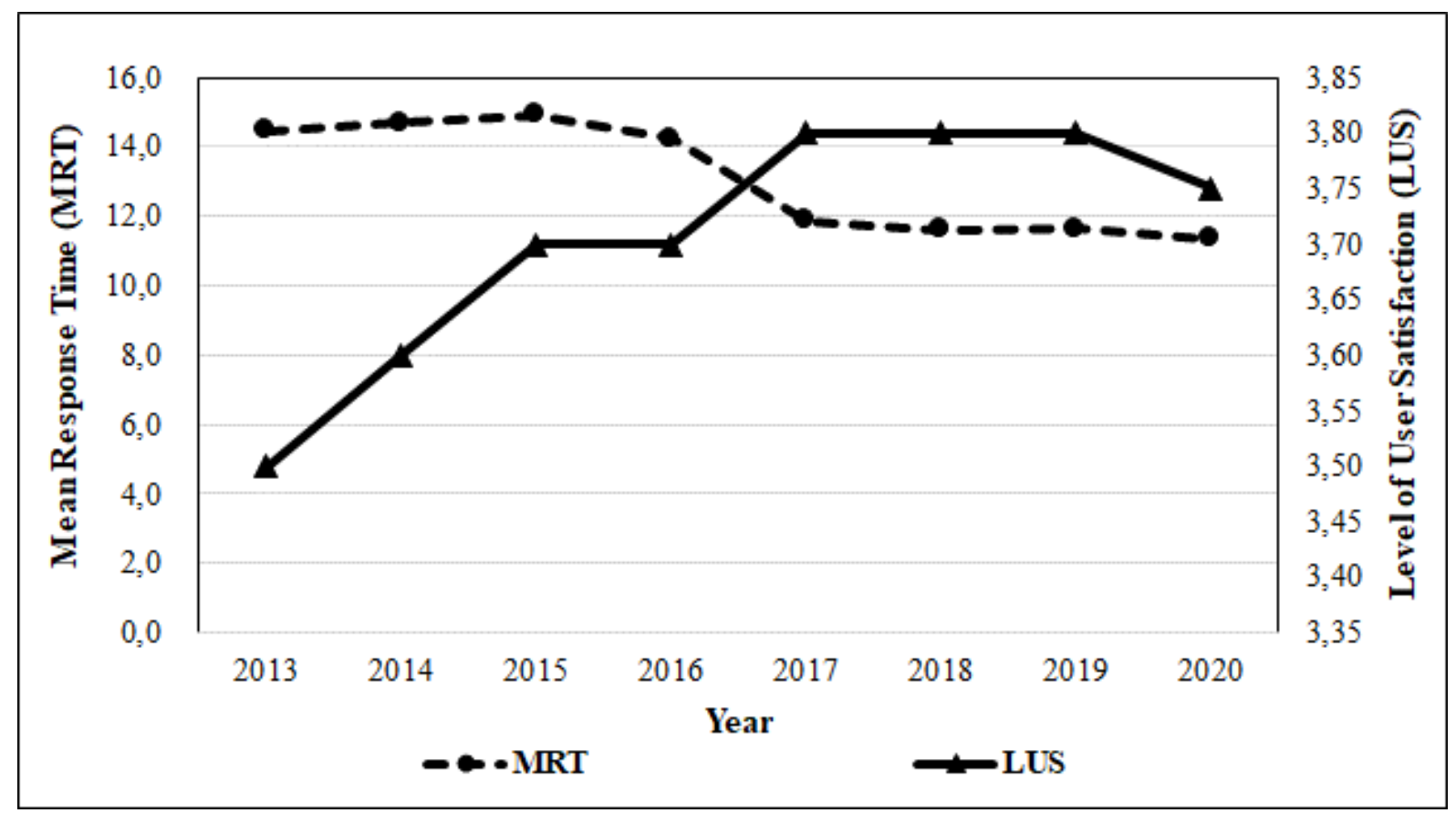

The evolution of indicator MRT shows, in one hand, a general trend where the more requested agencies and state-owned companies are keeping the response time between 12 and 15 days, thus above the half of the AIL's deadline (20 days); and, on the other hand, the evolution of indicator LUS shows a trend to be maintained a little bit above 3.8 (satisfactory, but not much satisfactory). In a translation of this Likert scale to a common scholar grade scale from 1 (the worst) to 10 (the best), the agencies and state-owned companies' performance in dealing with AIL would have a scholar grade 7.6. Then, it remains clear that the 26 most requested agencies and state-owned companies improved the quality of their service in dealing with AIL in the period from 2013 to 2017, decreasing a little bit the mean response time, but did not keep themselves in that pace of "continuous improvement" in the time following.

Other important observation, in Figure 4, is that there are two well defined levels of almost constant MRT in the period, the first since 2013 to 2016 and the second from 2017 to 2020, allowing us to suppose there is some another exogenous variable to be considered in the analytical model. Then, according to the recent political history of the country, this suddenly decrease in the level of MRT could be a consequence of the traumatic change of the President 
in 2016 by means of an impeachment process, followed by an effort of the new governments to improve the quality of services in the years of mandates ahead (2017-2020).

\section{Types of Responses}

The CGU's AIL data panel on the Internet also collects, stores and makes available to the users a dataset on the types of responses to each RFI, which are classified in seven groups:

I - Access Granted (AG): when the agency or state-owned company's response to the information requester (citizen) is totally granted, with no restriction;

II - Access Partially Granted (AP): when the response is only partially granted, with some reservation (some part of requested information is kept in secrecy);

III - Access Denied (AD): when the response is totally denied by the government body;

IV - Nonexistent Information (NI): when there's no information on the RFI's subject stored in the agency or state-owned company's files;

V - Incompetent Body (IB): when the requested government body does not deal with the subject of the RFI;

VI - Not Scope (NS): when the RFI's subject is not in compliance with the AIL;

VII - Duplicate/Replicated Request (DR): when the same RFI's subject appears twice or more times in the system (by the same user).

Actually, all data on AIL's operational indicators are the percentage of response types classified in each group, by agency and state-owned company, as shown in Figure 5 (with percentage shown in international standard notation).

Figure 5

Percentage of Response Types by Agency / State-Owned Company 


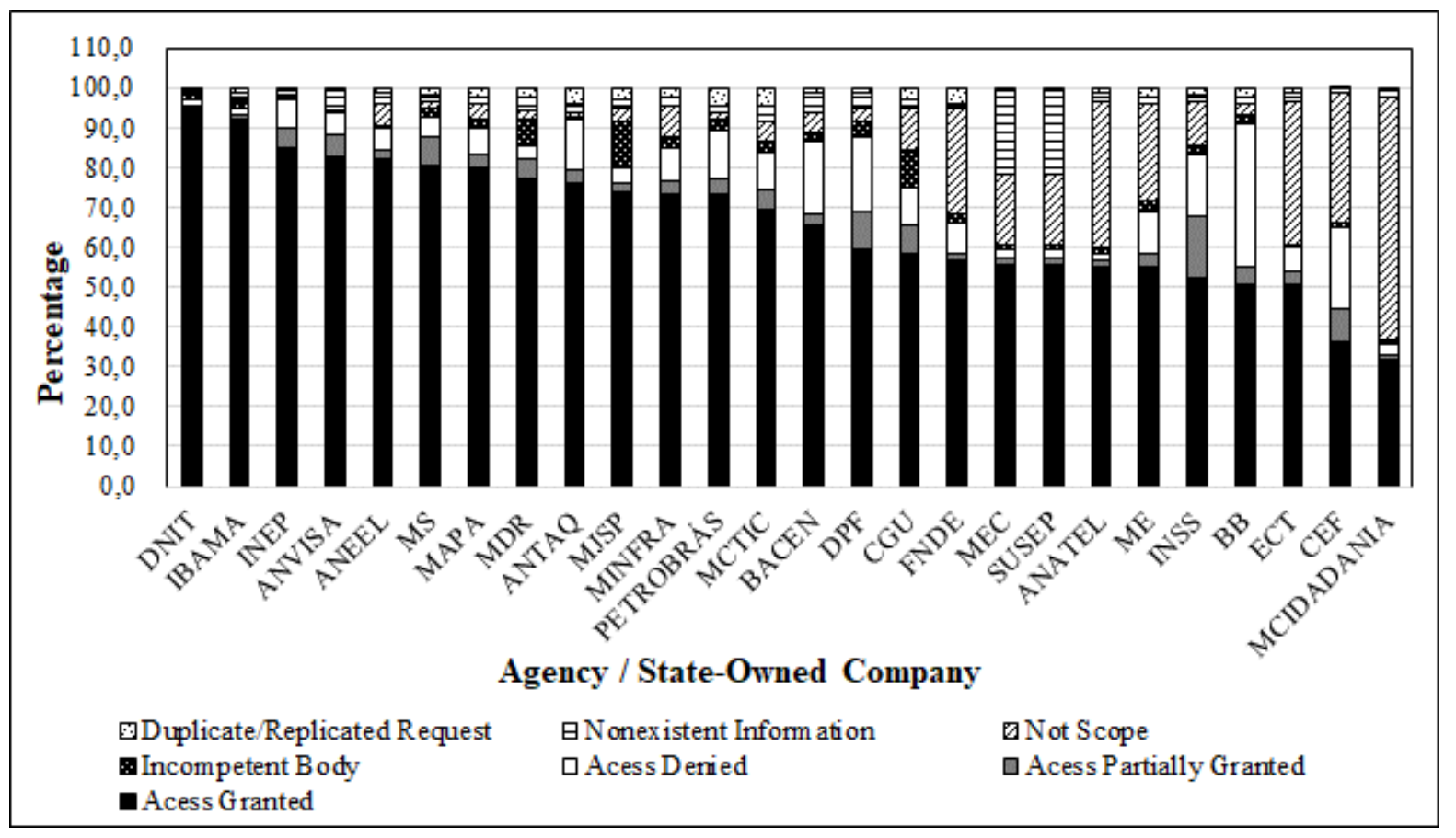

First of all, observing the data in Figure 5 it remains evident that the percentage of access granted varies a lot in the sample of agencies and state-owned companies, as shown in the statistical data of Table 3. For example, the National Department of Transport Infrastructure (DNIT), the best evaluated government body regarded the indicator Access Granted (AG), had a performance of $95.3 \%$, while the National Institute of Social Insurance had a performance of just $52.2 \%$ in that indicator.

Second, the types of alternate responses that contribute to not allow the access to information also varies in some extent; and third, the percentage of the indicator regarding "not scope" (NS) responses is alarming high in some government bodies. As expected, access is denied more in security and financing government bodies (state-owned banks), where there is more information protected by some secrecy in law (personal data, prosecuting data, business data, financing data, and so on) - the Bank of Brazil shows the highest value of the indicator Access Denied (AD), with 36.3\%.

In Table 3 empirical data reveals that Federal Government in Brazil has a high level of positive responses to citizens with regard to the AIL. As a statistical mean, the indicator AG 
(Access Granted) shows that $67.6 \%$ of all RFI has a full response of the government body to the requester citizen. It is important to point out this outcome with a benchmark with resulting data of other researches (notwithstanding the eventual lapse of time between them), like the one published by the Open Society Institute (OSI, 2006), where the information is granted to citizens in other countries with a by far lower level of completeness.

Table 3

Statistics on Response Types in Brazilian Federal Government

\begin{tabular}{lccccccc}
\hline \multirow{2}{*}{$\begin{array}{c}\text { Statistical } \\
\text { Parameter }\end{array}$} & AG & AP & AD & NI & IB & NS & DR \\
\cline { 2 - 8 } Maximum & 95.3 & 15.7 & 36.3 & 21.3 & 11.6 & 60.9 & 4.4 \\
\hline Minimum & 31.7 & 0.3 & 1.3 & 0.2 & 0.5 & 0.0 & 0.3 \\
\hline Mean & 67.6 & 3.6 & 6.9 & 2.1 & 2.0 & 4.8 & 1.7 \\
\hline Standard Deviation & 16.0 & 3.2 & 7.7 & 5.2 & 2.6 & 15.0 & 1.2 \\
\hline Variation Coefficient & 0.236 & 0.895 & 1.131 & 2.540 & 1.303 & 3.166 & 0.717 \\
\hline
\end{tabular}

If in Figure 5 one can see some range (variance) in the indicator AG (Access Granted), data in Table 3 also show even major ranges amongst the other indicators of response type. While the statistical variation coefficient of indicator AG is 0.236 (considered a low value), this statistical parameter is much higher related to NI (Nonexistent Information), with value 2.540, and the highest one concerning the indicator NS (Not Scope), with value 3.166.

It is remarkable the situation of the AIL's implementation concerning the indicator NS (Not Scope), with a clear trend observed in Figure 5: in nine out of the worst ten government bodies in AG (Access Granted) research data show that a high percentage of RFI is not in compliance with the AIL. The users (citizens) seem to request information not compliant with the AIL more frequently to the Ministry of Citizenship (MCIDADANIA), with the indicator NS (Not Scope) valued in 60.9\%, followed by the National Agency of Telecommunications 
(ANATEL), with 36.4\%, Brazilian Post and Telegraph Company (ECT), with 36.2\%, and Federal Savings Bank (CEF), with 33.0\%.

As seen in Table 3, the percentages of responses arguing there is not the requested information in the addressed government body (indicator NI), or that the requested government body is not the right one, with the common saying "it is not here" (indicator IB), also vary significantly amongst the agencies and state-owned companies.

\section{Conclusion}

In our research about the performance of the Access to Information Law's (AIL) implementation process in the Brazilian Federal Government we assumed two premises of a realistic scenario where the citizens: i) are seeking for relevant information mainly for their own interest (and not, necessarily, to grant a public interest); ii) do not know a priori what kind of information they should receive. This scenario is compliant with the database used in the research, where the citizens are expecting a satisfactory service and the government body's response assessed by the citizen could then be positive, negative or neutral according to their (subjective) personal expectations.

However, the literature shows several cognitive pathways one could reason on the possible citizens mind state in the process of building their expectancies about a (private or public) service provider, which will be crucial to one understand the real meaning of the user satisfaction indicators in any scenario of relationship between a service supplier organisation and its customers. In the face of this reality, we need to consider the cognitive complexity of the Access to Information Law (AIL)'s implementation process, where the ExpectancyDisconfirmation Theory (EDT) provides us a psychological framework to reasoning on the citizens' mind state when they are accessing governmental information through a system available in the Internet. 
In one hand, the empirical data sample used to build a time series related to the implementation process of the AIL in the Brazilian Federal Government revealed that in the first eight years the citizens became more interested in the access to information, with an increase in the indicator Request for Information (RFI) from 1,606 to 1,965 by agency or stateowned company, confirming the former conclusions of Mabilard (2019) in 14 other countries. On the other hand, the research data revealed that government bodies indicator Mean Response Time (MRT) did not decrease too much (from 14.5 days to 11.4 days) and the indicator Level of User Satisfaction (LUS) did not increase significantly (from 3.5 to 3.8 ) in the period, showing the user satisfaction did not changed too much in the implementation period.

Considering outstanding performances, on the one hand (in the positive side) one can observe that some government bodies have already responded the citizen's RFI with the highest possible rank related to the indicator AG (Access Granted), such as National Department of Transport Infrastructure (DNIT) (95.3\%) and Brazilian Institute of Environment and Renewable Natural Resources (IBAMA) (92.1\%). Other positive point, considering the AG (Access Granted) as the main indicator of the public policy of transparency based on AIL in Brazil, is that the mean performance of this indicator is of $67.6 \%$ between 2013 and 2020, with what we can conclude it is good, but there being still a room for improvement.

On the other hand (in the negative side), the alarming revelation is that there are some government bodies deserving an effort of a broad social communication about the scope of the AIL addressed to their customers in the population. The indicator NS (Not Scope) shows very high values in these cases, with more than one out of three citizens' requests for information (60.9\% in the worst case) responded with the observation of non compliance.

Considering the Brazilian Federal Government's effort to implement the access to information in the last decade and the importance of the public services provided by this instance of government in the country, the research data revealed that Brazil is in a relatively 
good position regarding the implementation of the AIL, reinforcing former assessments of research centers. One last conclusion, based on the experience of collecting data to the research, is that governments which have well-designed business processes and computing systems to implement the access to information have met the main requirements to move faster after the law was passed by Parliament. 


\section{References}

Bateson, G. (2002). Mind and nature: a necessary unity. Cresskill (New Jersey, EUA): Hampton.

Birchler, U. and Bütler, M. (2007). Information Economics. Routledge.

Bittencourt, C., Estima, J. and Pestana, G. (2019). Open Data Initiatives in Brazil. 14th Iberian Conference on Information Systems and Technologies (CISTI) of the Institute of Electrical and Electronics Engineers (IEEE), Coimbra, Portugal, 19-22 June 2019. Piscataway, New Jersey (USA): IEEE. https://ieeexplore.ieee.org/document/8760592.

Chatterjee, R., Suy, R. (2019). An Overview of Citizen Satisfaction with Public Service: Based on the Model of Expectancy Disconfirmation. Open Journal of Social Sciences, (7): 243-258. https://www.researchgate.net/publication/332507996_An_Overview_of_Citizen_Satisfaction _with_Public_Service_Based_on_the_Model_of_Expectancy_Disconfirmation.

Choo, C. W. (2005). The Knowing Organization: How Organizations Use Information to Construct Meaning, Create Knowledge, and Make Decisions. 2. ed., Oxford University.

Fundação Getúlio Vargas (2017). Open Data Index for Brazil. Report, FGV. https://blog.okfn.org/files/2017/05/OpenDataIndexBrazil2017.pdf.

Grimmelikhuijsen, S., Porumbescu, G. A. (2017). Reconsidering the Expectancy Disconfirmation Model: three Experimental Replications. Public Management Review, vol. 19 (9): 1,272-1,292. https://www.tandfonline.com/doi/full/10.1080/14719037.2017.1282000.

Joshil, A., Kale, S., Chandel, S., Pal, D. K. (2015). Likert Scale: Explored and Explained. British Journal of Applied Science \& Technology, vol. $7 \quad$ (4): 396-403. https://www.researchgate.net/publication/276394797_Likert_Scale_Explored_and_Explained.

Mabilard, V. (2016). Much Variation Seen in FOI Request Volumes in 11 Countries. Report, FeedomInfo.org. http://www.freedominfo.org/2016/09/much-variation-see-in-foi-requestvolumes-in-11-countries/.

Mabilard, V., Sofia, A., Pasquier, M. (2019). The Use and Effects of Access to Information Laws: a Study in 14 Countries. Report, Université de Lausanne. 
https://www.researchgate.net/publication/337678850_The_Use_and_Effects_of_Access_to_I nformation_Laws_A_study_in_14_countries.

Neumann, L. (2002). Acceso a la Informacion: la Llave para la Democracia. Report, El Centro Carter. https://www.cartercenter.org/resources/pdfs/peace/americas/ati-llave-para-democracia.pdf.

Oliver, R. L. (1980). A Cognitive Model of the Antecedents of Satisfaction Decisions. Journal of Marketing Research, vol. 17: 46-49. https://www.jstor.org/stable/3150499?seq=1.

Oliver, R. L. (1977). Effect of Expectation and Disconfirmation on Post-Exposure Product Evaluations: an Alternative Interpretation. Journal of Applied Psychology, vol. 62 (4): 480-486. https://psycnet.apa.org/record/1978-13415-001.

Open Society Institute (2006). Transparency and Silence: a Survey of Access to Information Laws and $\begin{array}{lllll}\text { Practices } & \text { in } & \text { Countries. } & \text { Report, }\end{array}$ https://www.justiceinitiative.org/publications/transparency-and-silence-survey-accessinformation-laws-and-practices-14-countries.

Organisation for Economic Co-operation and Development (2001). OECD Handbook on Information, Consultation and Public Participation in Policy-Making. Report drafted by Marc Gramberger, OECD. https://www.internationalbudget.org/wp-content/uploads/Citizens-as-Partners-OECDHandbook.pdf.

Purvis, R., Zagenczyk, T. J., McCray, G. E. (2015). What's in it for me? Using expectancy theory and climate to explain stakeholder participation, its direction and intensity. International Journal of $\begin{array}{lllll}\text { Project } & \text { Management. } & \text { 3ol. }\end{array}$ https://www.researchgate.net/publication/263201403_What's_in_it_for_me_Using_expectanc y_theory_and_climate_to_explain_stakeholder_participation_its_direction_and_intensity.

Rodrigues, K. F. (2020). The politics of Brazil's access to information policies: history and coalitions. Journal of Public Administration, Rio de Janeiro, vol. 54 (1): 142-161. https://www.scielo.br/pdf/rap/v54n1/en_1982-3134-rap-54-01-142.pdf.

Shannon, C. E. (1948). A Mathematical Theory of Communication. The Bell System Technical Journal, vol. 27: 379-423. 
Stiglitz, J. E. (2009). Selected Works of Joseph E. Stiglitz: Volume I: Information and Economic Analysis. Oxford University.

United Nations Educational, Scientific and Cultural Organisation (2020). Concept Note for the Celebration of the International Day for Universal Access to Information (IDUAI) 2020. Report, UNESCO. https://en.unesco.org/sites/default/files/cn_iduai_2020.pdf.

United Nations Educational, Scientific and Cultural Organisation (2019). Powering Sustainable Development with Access to Information. Report, UNESCO. https://unesdoc.unesco.org/ark:/48223/pf0000369160.

Van de Walle, S. (2018). Explaining Citizen Satisfaction and Dissatisfaction with Public Services. In: Ongaro, E. \& Van Thiel, S. (eds.). The Palgrave Handbook of Public Administration and Management in Europe. London: Palgrave Macmillan, 227-241.

Weick, K. E. (1995). Sensemaking in Organizations. SAGE.

Worthy, B. (2015). Access to Information in the UK and India. Revue Internationale des Governements Ouverts, vol. 2. https://www.ojs.imodev.org/index.php/RIGO/article/view/18/90.

Yüksel, A., Yüksel, F. (2007). Consumer Satisfaction Theories: a Critical Review. In: Yüksel, A. Tourist Satisfaction and Complaining Behavior, Nova Science. https://www.researchgate.net/publication/258224400_Consumer_Satisfaction_Theories_A_Cr itical_Review. 